DOI No: http://dx.doi.org/10.29228/Joh.49832

Authenticity process is conducted by

Makale Türü: Araştırma makalesi

Geliş Tarihi: 06-03-2021

Kabul Tarihi: 20-04-2021

On-line Yayın: 30-04-2021
Article Type: Research article Submitted: 06-03-2021 Accepted: 20-04-2021 Published Online: 30-04-2021

Atıf Bilgisi / Reference Information

Dedeoğlu, H., Baş, Ö., Kesik, C. \& Çelik, S. (2021). Elementary School Teachers' Experiences Of Information And Communication Technologies During Covid19 Pandemic. Journal of History School, 51, 1119-1142.

\title{
ELEMENTARY SCHOOL TEACHERS' EXPERIENCES OF INFORMATION AND COMMUNICATION TECHNOLOGIES DURING COVID-19 PANDEMIC ${ }^{1}$

\author{
Hakan DEDEOĞLU² ${ }^{2}$ Özlem BAŞ ${ }^{3}$, Cengiz KESİK ${ }^{4} \&$ Serkan ÇELIK ${ }^{5}$
}

\begin{abstract}
This paper aims to describe the experiences of elementary school teachers who teach in schools of different socio-economic levels with information and communication technologies (ICT) during Covid-19 pandemic. This study, designed in qualitative method, is a holistic multiple case study. The data collected from 16 teachers who were chosen in deviant case sampling method- one of the purposeful sampling methods- through standardised interview forms were put to content analysis. The results obtained in this study suggested that elementary school teachers who teach in schools of differing socio-economic

\footnotetext{
${ }^{1}$ Author impact rate in article writing: $1^{\text {st }}$ author: $\% 25,2^{\text {nd }}$ author: $\% 25,3^{\text {rd }}$ author: $25,4^{\text {th }}$ author: $\%$ 25. Ethics committee approval for this article was obtained at Hacettepe University with the number 35853172-300 and meeting number.

${ }^{2}$ Associate Professor, Hacettepe University, Education Faculty, Elemantary Education Department, dede@ hacettepe.edu.tr, Orcid: 0000-0003-2436-7010

${ }^{3}$ Associate Professor, Hacettepe University, Education Faculty, Elemantary Education Department, ozlembas@ hacettepe.edu.tr, Orcid: 0000-0002-0716-103X

${ }^{4}$ Research Assistant, Harran University, Education Faculty, Elemantary Education Department, cengiz_kesik@hotmail.com, Orcid: 0000-0001-9777-0076

5 Professor, Hacettepe University, Education Faculty, Elemantary Education Department, sercelikan@gmail.com, Orcid: 0000-0002-4935-1499
} 


\section{Hakan DEDEOĞLU, Özlem BAŞ, Cengiz KESIKK \& Serkan ÇELIKK}

levels described digital divide which they considered as an obstacle in front of equality of opportunity in education and that they thought Covid-19 epidemic increased the interactions between all stakeholders available in ICT ecosystem in educational environments. While the teachers with adequate technological awareness and skills tried to cope with the restrictions by using freeware resources in the process, the teachers in private schools closed the gap even though they were inadequate in using technology because resources and environments were provided for them. Another important result obtained in the study was that trying to implement ICT at the level of primary school during Covid-19 caused certain difficulties for students due to their age.

Keywords: Information and Communication Technologies, Elementary School Teacher, Digital Divide, Covid-19.

\section{INTRODUCTION}

Information and communication Technologies [ICT] are heavily used today in access to knowledge as well as in creating, spreading, storing, managing knowledge and in communicating. The increasing effects of ICT technologies due to Covid-19 on social life have also been reflected into educational environments, undoubtedly. Using ICT in teaching and as an instrument in teaching is a practice in parallel to the dependence of configuring knowledge on prior knowledge in constructivist approach and to the change of teachers' roles in this context (Cited in Kuiper and Volman, p. 244; Jonassen, 1996, Bransford, Brown and Cocking, 1999). Ministry of National Education's (MoNE) 2015-2019 strategic plan that teachers would be offered in-service training in using the educational informatics network (EBA) actively and thus FATIH project was put into practice (Kurtdere Fidan, Erbasan and Kolsuz, 2016, p. 627). Besides, the target of raising leader teachers who have acquired the culture of using actively and developing digital content and of making the culture widespread in schools was set in 2023 vision document (2023 Vision document, 2019, p. 74). Since face to face education was suspended in March 2020 in Turkey as in the whole world due to Covid-19 pandemic, distance education was put into practice at all stages of education in Turkey by the Ministry of National Education [MoNE] and by the Council of Higher Education, the EBA was updated, the video-based lessons were taught on TV for nationwide access and solutions of educational access at school level and at grade level were introduced. It was observed in this process that distance education was conducted through synchronic commercial platforms in private schools but that it was performed by using free distance learning channels with individual efforts of elementary school teachers in state schools. The process introduced new and important experiences for people in educational institutions. According to the distance education evaluation report (2020) prepared by Turkish 
Elementary School Teachers' Experiences of Information and Communication...

educational volunteers foundation, the rate of students who followed EBA regularly every day during covid-19 pandemic was $69 \%$ while the rate of participation in live classes was $11 \%$. During pandemic, $83 \%$ of access to distance education was through TV channels. Of the students 50\% used their computer, 59\% used their mobile phone, 28\% used their tablet PC and 4\% used no devices in distance education. The rate of students who saw their teacher regularly every week was $48 \%$ while the rate of those who saw their teacher once or twice a week was $31 \%$ and the rate of those who saw their teacher once or twice in the last 90 days was $21 \%$. The rate of those who communicated with their teacher irregularly or rarely was $51 \%$.

Even though information and communication technologies have a large impact across the world, the impacts vary due to socio-economic level, the power of relations or inadequate conditions (Pena-Lopez, 2010). There are remarkable studies which emphasise that the primary obstacle in front of elementary school teachers' use of information technologies is their lack of having adequate knowledge and skills in using those technologies (Karaman and Kurfall, 2008). It is also reported in the literature that teachers who have computers and internet connection that they can use at home and in their classes benefit more from information technologies for such purposes as doing research on the internet and using educational materials in their classes (Li and Ranieri, 2013; Günzdüz, 2010). Van Dijk (2006, 221-222) describes digital divide as the gap between those who can access to information technologies and those who cannot while stating that attention was called to the concept of digital divide in the late 1990s in unequal access to the new media and in the use of technology. Li and Ranieri (2013) say that students who come from rural areas and immigrant students receive low scores from internet inequality indicators (digital access, autonomy of use, social support, internet usage and self-efficacy) and therefore they are disadvantaged in using the internet when compared to students who come from urban areas. These results are generally consistent with the data coming from OECD countries and they confirm that digital divide represents great social difficulty and they also demonstrate that schools have to develop effective strategies to balance the social and learning opportunities between students. Thus, there is digital divide among the schools, families, students in different socio-economic levels and regions (Gündüz, 2010).

The concept of digital divide also emerges in Turkey's failure in international examinations. Yıldız Durak and Seferoğlu (2016) report that Turkey is behind Korea and Finland in access to information technologies- which are influential in achievement of PISA examination. On the other hand, it was also found in the study that students' reading, comprehension and recalling strategies also differed significantly according to whether they had access to the Internet at 
home. The ICT experiences and observations of teachers who teach in schools with varying socio-economic levels in Turkey should be demonstrated from the perspectives described above. The current study aims to describe elementary school teachers' experiences of ICT on the basis of the digital divide by seeking answers to the following research questions:

1. How do elementary school teachers who teach in schools with differing socio-economic levels use ICT in their classes?

2. What difficulties do they encounter in using ICT?

3. What do they think of the effects of varying possibilities to access to technology due to socio-economic restrictions on learning environment, on students' equal access to educational opportunities and on their personal development?

4. What are their evaluations about the effectiveness of the ecosystem in which the elements of ICT are available?

\section{METHOD}

This study was designed as a holistic multiple case study. In holistic multiple case studies, more than one case is considered as a whole and then they are compared (Yıldırım and Şimşek, 2016, 301; Büyüköztürk, Çakmak, Akgün, Karadeniz and Demirel, 2013, 249). In this context, Miles and Huberman's (2015, 132) thematic conceptual matrices were used for comparing the findings obtained.

\section{The Study Group}

Deviant case sampling, a method of purposeful sampling, was used in this study. Deviant case sampling requires that situations limited in number but rich in information which can be put to -depth analysis are studied (Yıldırım and Şimşek, 2016, 119). Accordingly, 16 teachers 8 of whom were teaching in a school with low socio-economic level and 8 of whom were teaching in a school with high socioeconomic level were included in the study groupin Ankara. The average income reported by Turkish Statistical Institution for the year 2018 was taken into consideration (gross domestic product per person in Ankara was 60,249 TL) and care was taken so that the students were below or above the value (https://biruni.tuik.gov.tr/ilgosterge/?locale=tr).

\section{Data Collection and Analysis}

Standardised open-ended interview forms were used in collecting the research data. The 19 interview questions prepared for our purposes were sent to 
the teachers synchronously and asynchronously during Covid-19 pandemic. The oral and written answers to the questions were archived and stored. Content analysis- one of the document analysis methods used in qualitative research- was used in analysing the answers. The participants' answers to the questions were coded by two researchers separately. The formula of $\{$ Reliability=agreement/agreement + disagreement $]$ suggested by Miles and Huberman (1994) was used in calculating the consistency between the two researchers. Thus, the consistency coefficient between the researchers was found as $86 \%$. The coding made by the researchers can be said to be consistent since the value was above $70 \%$.

\section{Validity and Reliability}

The codes were included in the matrices in the relevant categories and themes. The codes were examined by two experts in educational technologies, and then the codes were given their final shape. In this way, depth-focused data collection, expert analysis and participant confirmation were secured and thus persuasiveness was strengthened, purposeful sampling was chosen for transferability and consistency was checked by two researchers, participant confirmation was received, and confirmability was secured as a result.

\section{FINDINGS and INTERPRETATION}

This section presents the findings obtained through analysis of the data and the interpretations made. The findings were presented on the basis of the four main themes which emerged in the scope of this study. The themes were the use of ICT during Covid-19 pandemic, the difficulties encountered in using the ICT in this process and the recommendations for solutions, the economic and sociological limitations during Covid-19 pandemic and the ecosystem in which the elements of ICT were available during Covid-19 pandemic. 


\section{Hakan DEDEOĞLU, Özlem BAŞ, Cengiz KESİK \& Serkan ÇELIKK}

\section{Matrix -1}

The Categories and Codes in the Theme of the Use of ICT during Covid-19 Pandemic

\begin{tabular}{|c|c|c|}
\hline \multicolumn{3}{|c|}{$\begin{array}{l}\text { THEME: The Use of ICT During Covid-19 Pandemic } \\
\text { Matrix-1 }\end{array}$} \\
\hline Categories & $\begin{array}{l}\text { A state school with low socio- } \\
\text { economic level }\end{array}$ & $\begin{array}{c}\text { A private school with } \\
\text { high socio-economic level }\end{array}$ \\
\hline $\begin{array}{l}\text { Teachers } \\
\text { competent } \\
\text { in using } \\
\text { technology }\end{array}$ & $\begin{array}{l}\text { - EBA, ZOOM, Teams, Okulistik, } \\
\text { Fatih Project, tablet PCs, phones, } \\
\text { computers come into mind } \\
\text { - Reaching students often with smart } \\
\text { mobile phones } \\
\text { - Introducing out-of-the-school } \\
\text { learning environments such as } \\
\text { museums, historical places and } \\
\text { archaeological sites on virtual } \\
\text { platforms } \\
\text { - Not giving homework which will } \\
\text { necessitate the use of technology } \\
\text { since there are no students who can } \\
\text { equally use technological } \\
\text { possibilities on every occasion. } \\
\text { - Calling students on the phone and } \\
\text { leading them to EBA. } \\
\text { - Presenting a point of teaching on } \\
\text { one's own Youtube channel, teaching } \\
\text { lessons live on Facebook } \\
\text { - Using Google questionnaire for } \\
\text { preparing a multiple-choice test }\end{array}$ & $\begin{array}{l}\text { - Smart board programmes, social } \\
\text { communication networks, Edmodo, } \\
\text { class dojo, twinkle, sparkle box, } \\
\text { Morpa campus, Vitamin, Youtube, } \\
\text { piterest, Google Drive, Google } \\
\text { Doc, Google Slide, Google Sheets, } \\
\text { Google classroom, seesaw, } \\
\text { brainpop junior, Okulistik, Quizizz, } \\
\text { Super Teacher worksheets, etc. } \\
\text { come into mind. } \\
\text { - Students have their own computer } \\
\text { at home. } \\
\text { - Students who cannot come to } \\
\text { school send their paper on } \\
\text { technological platforms. } \\
\text { - Although the school is described as } \\
\text { an Apple school, students cannot do } \\
\text { much in out-of-the-school tasks } \\
\text { because they have not taken a } \\
\text { computer course } \\
\text { - Students often use technological } \\
\text { tools in learning tasks }\end{array}$ \\
\hline $\begin{array}{l}\text { Teachers } \\
\text { incompetent } \\
\text { in using } \\
\text { technology }\end{array}$ & $\begin{array}{l}\text { - The internet, computers, educational } \\
\text { software, didactic videos, smart } \\
\text { phones, social media, EBA TV come } \\
\text { into mind. } \\
\text { - Sending learning tasks through } \\
\text { WhatsApp } \\
\text { - Those who have technological } \\
\text { possibilities can access to the } \\
\text { activities but those who do not have } \\
\text { those possibilities cannot access. } \\
\text { - Communication on the phone } \\
\text { because there are no students who } \\
\text { have computers. }\end{array}$ & $\begin{array}{l}\text { - Computers, projector, the internet, } \\
\text { smart phones, overhead projector, } \\
\text { memory sticks cameras, mp3 } \\
\text { players, photocopiers, printers } \\
\text { and scanners come into mind } \\
\text { - Using videos of focusing on } \\
\text { lessons, photos and the } \\
\text { blackboard } \\
\text { - Morpa campus, Vitamin, youtube, } \\
\text { pinterest, Google Drive, qr } \\
\text { scanner, kahoot, popplet lite are } \\
\text { used in classes } \\
\text { - Having lite lessons with children } \\
\text { through Padlet application }\end{array}$ \\
\hline
\end{tabular}

An analysis of Matrix 1 shows that the first remarkable information especially on teachers who teach in state schools with low socio-economic level is that students try to have access to technological content with their smart phones 
and that they do not have their own computer at home. Some students, on the other hand, do not fulfil the task of out-of-the-school learning tasks. Therefore, the most important resource for teachers is EBA TV, WhatsApp and social media. A participant who stated his/her view in this respect described the situation as in the following:

"Up to date" learning means re-configuring the technologies and our soul with the students who I cannot touch due to pandemic. I am learning that everything can be done in every situation and that the bridges we build due to technology-in which I am (we are) not competent can dress our wounds in one way or another. We see the real "life" study together through live lessons, social media or smart phones (Ö7)."

The fact that the teachers in schools with high socio-economic level use more specific programmes. Thus, the students in such schools have their personal computers concretises the digital divide in this theme. A participant gave the following example for students' making use of technological possibilities:

"Students can work with their friends' even outside the school and they can upload their work on Google Classroom and share with the teacher; or they can use the test for practice whenever they want. They can also comment on the discussion topics that the teacher sends in the Google Classroom. " (Ö11)

On comparing the data shown in Matrix-1 vertically, technological possibilities affect students with low socio-economic level no matter if teachers are competent or incompetent in using technology. It is because while the teachers who teach in such schools make effort to use resources open to access such as opening a Youtube channel or live broadcasting on Facebook, the students of teachers who are incompetent in using technology in the same category cannot even have access to such possibilities. The teachers who work in schools with high socio-economic level can compensate for the inadequacies even if they do not have adequate background individually since they are provided the technological resources (Morpa Campus, Okulistic, Padlet, etc.) by their school. 


\section{Hakan DEDEOĞLU, Özlem BAŞ, Cengiz KESİK \& Serkan ÇELIKK}

\section{Matrix-2}

The Categories and Codes in the Theme of Difficulties Encountered in Using ICT in this process and the Recommendations for Solutions

\begin{tabular}{|c|c|c|}
\hline \multicolumn{3}{|c|}{$\begin{array}{c}\text { Theme: Difficulties Encountered In Using Ict In This Process And The Recommendations } \\
\text { for Solutions. Matrix-2 }\end{array}$} \\
\hline Categories & $\begin{array}{l}\text { A state school with low socio- } \\
\text { economic level }\end{array}$ & $\begin{array}{l}\text { A private school with high socio- } \\
\text { economic level }\end{array}$ \\
\hline $\begin{array}{l}\text { Teachers } \\
\text { competent } \\
\text { in using } \\
\text { technology }\end{array}$ & $\begin{array}{l}\text { - Difficulty in reaching students with } \\
\text { learning difficulties or immigrant } \\
\text { students due to lack of family } \\
\text { support } \\
\text { - Difficulties in participating in the } \\
\text { connection, difficulties in } \\
\text { sustaining the connection due to } \\
\text { students' age } \\
\text { - Disconnection } \\
\text { - Offering continuous training in } \\
\text { using technology } \\
\text { - ICT classrooms should be re- } \\
\text { arranged and continuously updated } \\
\text { - Parents' support should be secured. } \\
\text { - deficiencies should be eliminated } \\
\text { by MoNE }\end{array}$ & $\begin{array}{l}\text { - Inadequate use of Ipad in primary } \\
\text { schools } \\
\text { - Parents' expectations } \\
\text { - Problems stemming from differences } \\
\text { in parents' equipment } \\
\text { - Teachers' internet speed and students' } \\
\text { internet speed. } \\
\text { - Students' short attention span due to } \\
\text { their age } \\
\text { - Teachers' receiving support from the } \\
\text { ICT or computer department when } \\
\text { they have difficulty } \\
\text { - Bringing attention span under control } \\
\text { by having online lessons with groups } \\
\text { of seven } \\
\text { - Talking about recommendations for } \\
\text { - wolution through meetings at school. } \\
\text { - Waiting for the elimination of } \\
\text { disruptions in internet connection }\end{array}$ \\
\hline $\begin{array}{l}\text { Teachers } \\
\text { incompetent } \\
\text { in using } \\
\text { technology }\end{array}$ & $\begin{array}{l}\text { - Inequality of opportunities between } \\
\text { children, children's lack of } \\
\text { computers of their own, the } \\
\text { internet, and sometimes of smart } \\
\text { phones at home } \\
\text { - Leaving the internet connection and } \\
\text { computer possibilities to the } \\
\text { personal efforts of teachers } \\
\text { - Personal computers' failure to catch } \\
\text { up with technology } \\
\text { - Having too crowded classrooms } \\
\text { - Reducing the number of students in } \\
\text { classrooms } \\
\text { - Giving homework which requires } \\
\text { no technology } \\
\text { - Setting up ties through WhatsApp } \\
\text { - TV channels' continuing } \\
\text { educational broadcasting } \\
\text { - Using classrooms which have a } \\
\text { projector and internet connection } \\
\text { - Offering in-service training }\end{array}$ & $\begin{array}{l}\text { - Small age group of students } \\
\text { - Students' attitudes towards play } \\
\text { - Students' destroying the page setup on } \\
\text { the computer } \\
\text { - Computer settings } \\
\text { - Students' lack of technological skills } \\
\text { to use the hardware } \\
\text { - Lack of content which is linguistically } \\
\text { and culturally suitable to the } \\
\text { curriculum and the level }\end{array}$ \\
\hline
\end{tabular}


Elementary School Teachers’ Experiences of Information and Communication...

Even though the difficulties that teachers who teach in state schools with low socio-economic level and who are competent in using technology and the teachers who teach in private schools with high socio-economic level and who are competent in using technology encounter during Covid-19 cause limitations due to students' age, problems related to access to technology is experienced on one side whereas routine hardware-related problems are experienced on the other side. That is to say, while teachers who teach in state schools with low socio-economic level have difficulty in reaching students, teachers who teach in private schools with high socio-economic level mention codes such as parents' expectations and internet speed. A finding which was worth attention was that the relevant departments of information technologies which could recommend solutions when teachers had problems interfered in the process in private schools whereas teachers in state schools had to wait for in-service training and family support in such cases.

"I wait when I have problems in internet speed or in connection, and I continue after the problem is solved. As to the students' attention span, I have lessons with students in groups of 7 to have more student participation and to have less distraction, and I continuously try to motivate them." (Ö9)

"I phoned my students one by one and checked if they had internet connection. After that, I tried to communicate with the parents by using their smart phones. I cannot reach two of my students because they do not have internet connection. It is important that families give support. You cannot reach students if you cannot receive support in this respect." (Ö3)

While the teachers who are competent in technological issues but who cannot provide their students with sufficient access due to socio-economic reasons tried to reach their students on the phone, the teachers who worked in private schools with high socio-economic level did not have such problems and they had expectations of better quality process of access to education. According to the codes in Matrix-2, the teachers who taught in state schools with low socioeconomic level and who were incompetent in using technology mentioned inequality of opportunities that children faced while the teachers who taught in private schools with high socio-economic level and who were incompetent in using technology mentioned students' inadequacy in using computers or their attitudes toward technology. The digital divide which emerged here was evident in the raw data presented below:

"Inequality of opportunities that the children have is a big problem. While every classroom has no access to the internet, the classrooms which have access have problems of occasional disconnection. Your personal computer's inability to catch up with technology is still another problem. If the projector is working and if you need to turn it off when its light is heated (!), it is a nonsense problem. Another problem is that the curtain of the projector is not closed after it is opened... 
But the actual problem is the administrations' perspective of your complaint that the projector doe not work while the heating system in the classroom does not work efficiently or while the students' lavatory smells bad. We cannot provide children whose father lost their job due to the pandemic with technological support. Instead we prioritise psychological support and vital needs if any." (Ö7)

\section{Matrix-3}

The Categories and Codes in the Theme of Economic and Social Limitations during Covid-19

Theme: Economic And Sociological Limitations During Covid-19

Matrix-3

\begin{tabular}{|c|c|c|}
\hline Categories & $\begin{array}{l}\text { A state school with low } \\
\text { socio-economic level }\end{array}$ & $\begin{array}{l}\text { A private school with high socio- } \\
\text { economic level }\end{array}$ \\
\hline $\begin{array}{l}\text { Teachers } \\
\text { competent } \\
\text { in using } \\
\text { technology }\end{array}$ & $\begin{array}{l}\text { Weak communication with } \\
\text { students who live far from } \\
\text { the centre in distance } \\
\text { teaching, having } \\
\text { disconnections in the } \\
\text { internet } \\
\text { - Not having the same } \\
\text { technological possibilities } \\
\text { in their homes as other } \\
\text { students in the same class } \\
\text { and in the same school who } \\
\text { are different in socio- } \\
\text { economic status } \\
\text { - The children of parents who } \\
\text { have lower income are } \\
\text { more introvert and are less } \\
\text { familiar with technology... }\end{array}$ & $\begin{array}{l}\text { - Use which can sometimes be excessive } \\
\text { because their access to technology is easy } \\
\text { - Teachers' conversion of the use of } \\
\text { technology in groups into efficient } \\
\text { learning process } \\
\text { - Being able to follow technological } \\
\text { innovations } \\
\text { - Teachers' planning secures that students } \\
\text { understand what to do, how much to do } \\
\text { and when to do } \\
\text { - Technologies used outside the school } \\
\text { with parents' permission prepare fast } \\
\text { learning environments } \\
\text { - Children will be able to achieve success } \\
\text { in international technological } \\
\text { competitions at next grade levels and will } \\
\text { be able to take part in engineering level } \\
\text { activities }\end{array}$ \\
\hline $\begin{array}{l}\text { Teachers } \\
\text { incompetent } \\
\text { in using } \\
\text { technology }\end{array}$ & $\begin{array}{l}\text { - Lack of access to computers } \\
\text { or to the internet for some } \\
\text { of the students, } \\
\text { - The emergence of learning } \\
\text { deficiencies because } \\
\text { students cannot participate } \\
\text { in the process of distance } \\
\text { education }\end{array}$ & $\begin{array}{l}\text { - Important in the development of research } \\
\text { and enquiry skills } \\
\text { - Both important and risky in knowledge } \\
\text { literacy... } \\
\text { - They do not have problems in adapting } \\
\text { into modern life. } \\
\text { - They have the comfort of accessing to } \\
\text { knowledge faster } \\
\text { - They can state themselves more easily } \\
\text { because their self-confidence is } \\
\text { developed }\end{array}$ \\
\hline
\end{tabular}

As is clear from Matrix-3, the point of focus of all the teachers who teach in state schools with low socio-economic level in the theme of economic and sociological limitations is inequality of opportunities in education. It was stated 
Elementary School Teachers’ Experiences of Information and Communication...

that the situation caused students in schools with low socio-economic level to have learning deficiencies during distance education and that such students were observed to have lack of self-confidence in personal development. Therefore, economic limitations emerged as the fundamental elements in the codes mentioned by the teachers. The teachers who taught in private schools with high socioeconomic level, on the other hand, considered the students' situation in reaching technology mostly in terms of social development and made evaluations about the reflections of their access to educational opportunities into their business life in the future and into how to adapt into social life, and they said that the students' problem-solving skills and their self-confidence were developed in contrast to other groups of students. The data shown in Matrix-3 indicate the digital divide which is reflected into students' learning environments, educational opportunities and personal development according to the views stated by teachers who teach in both types of schools. Accordingly, the participants stated their views as in the following:

"I have difficulty in reaching them efficiently because they are disadvantaged (socio-economically). It, in fact, has impacts on all of us. We will all have difficulty while revising the subjects they have missed and trying to cover all the subjects when we come back to school." (Ö6)

"I think that children will be able to achieve success in international technological competitions at next grade levels and that they will be able to take pat in engineering level activities. Technology education started at earlier ages (at grade two) and such centres as Idealab and innovation centre became a place that especially high school students used actively." (Ö10)

Accordingly, it was demonstrated through codes that the groups of teachers communicated with their students, with other teachers, parents communicated with other parents by using the informatics infrastructure of their school during Covid19 pandemic. The obligatory and challenging process increased the interactions between all participants in the ecosystem in technological environments and accelerated communication. Communication between relevant participants is substantially important for the continuation of the process of distance education for almost all students and teachers who can access to technology. As it is evident from the codes in Matrix-4, the teachers who are competent in using technology help students to make academic progress and help to increase communication during Covid-19 but students cannot make progress in emotional development. Some of the teachers' views stated in this respect were as in the following: 


\section{Hakan DEDEOĞLU, Özlem BAŞ, Cengiz KESİK \& Serkan ÇELIKK}

\section{Matrix-4}

The Categories and Codes in the Theme of the ecosystem in which the Elements of ICT were Available during Covid-19 Pandemic

Theme: Thee Ecosystem In Which The Elements Of Ict Were Available During Covid 19

Matrix-4

\begin{tabular}{|c|c|c|}
\hline Categories & $\begin{array}{l}\text { A state school with low socio- } \\
\text { economic level }\end{array}$ & $\begin{array}{l}\text { A private school with high socio- } \\
\text { economic level }\end{array}$ \\
\hline $\begin{array}{l}\text { Teachers } \\
\text { competent } \\
\text { in using } \\
\text { technology }\end{array}$ & $\begin{array}{l}\text { The process functions much more } \\
\text { fruitfully with instant feedback } \\
\text { because it is an interactive process } \\
\text { and because all the stakeholders take } \\
\text { part in the learning-teaching } \\
\text { processes. } \\
\text { - Communicating fast, getting } \\
\text { feedback, becoming aware of what } \\
\text { children do from the perspective of } \\
\text { parents } \\
\text { - Administrators can monitor work } \\
\text { more easily, they give support and } \\
\text { ask for ideas } \\
\text { - Teachers are informed of each } \\
\text { other } \\
\text { - There should be technical } \\
\text { departments for interventions in } \\
\text { technical problems that can arise in } \\
\text { schools, and it should be facilitated } \\
\text { for teachers to benefit from } \\
\text { information technologies at the } \\
\text { maximum as support in solving the } \\
\text { problems }\end{array}$ & $\begin{array}{l}\text { - Trying to have close ties with } \\
\text { students in distance education even } \\
\text { though they are not close as the ones } \\
\text { in classroom environment } \\
\text { - Exchange of information with other } \\
\text { teachers } \\
\text { - Meetings with administrators about } \\
\text { support and communication } \\
\text { - Communication with parents secure } \\
\text { the continuity of lessons } \\
\text { - Parents help each other by } \\
\text { communicating with each other } \\
\text { - Information technology teacher helps } \\
\text { in terms of problems encountered in } \\
\text { software } \\
\text { - Academic progress was made } \\
\text { - Social development is insufficient } \\
\text { because there is no face to face } \\
\text { communication } \\
\text { - Students are devoid of peer teaching } \\
\text { - Monitoring students' development } \\
\text { with special programmes (Google } \\
\text { Forms, Google Slides, Google } \\
\text { Classroom, Seesaw) }\end{array}$ \\
\hline $\begin{array}{l}\text { Teachers } \\
\text { incompetent } \\
\text { in using } \\
\text { technology }\end{array}$ & $\begin{array}{l}\text { - Students are more enthusiastic } \\
\text { about learning } \\
\text { - Teachers support each other } \\
\text { - Information is shared with } \\
\text { administrators } \\
\text { - Resources are shared with parents } \\
\text { - A school coordinator was } \\
\text { appointed for the period of pandemic } \\
\text { - Teachers are trying to solve the } \\
\text { problems on their own because the } \\
\text { informatics infrastructure at school } \\
\text { has deficiencies }\end{array}$ & $\begin{array}{l}\text { - Collaborative relations are formed } \\
\text { - Exchange of information with } \\
\text { students } \\
\text { - Live connections and group meetings } \\
\text { - Communicating with administrators } \\
\text { - Following students' assignments } \\
\text { with parents... } \\
\text { - Faster communication }\end{array}$ \\
\hline
\end{tabular}

"I observed that we made progress towards the gains we wanted to have; because I observed during our live lessons that they participated in classes and I could give feedback on checking their learning at home, and I as well as they themselves could see what level they attained. Yet, I could observe the same 
Elementary School Teachers’ Experiences of Information and Communication...

progress in social development only for a certain period of time. That is to say, I observed that spending time on the internet with their friends for a certain period of time was not enough for them and that their emotional development was affected in a negative way because they could not see anybody. "(Ö3)

Another factor which caused digital divide especially during Covid-19 was that the teachers competent in using technology had monitored students' development through special programmes. Some of the statements made by teachers in this respect were as in the following:

"We could do the activities through 'Seesaw' with the third graders this year. Because Seesaw was a programme which our school demanded that we used we the third graders. You could observe which student did what activity and what and how they did it with the programme and you could give feedback." (Ö3)

However, the teacher with students who did not have those possibilities said,

"We owe much to information technologies in the period of epidemic. I used to say that I was a teacher who did not use technology enough to have interaction. But now I can reach the parents better. The kids have unbelievable ties between themselves and with me. That their motivation is not diminished gives me energy and it seems unbelievable to me.... The energy is also reflected into the parents in the same way. Their interactions with other parents and with me is encouraging me. I have never heard problems between the teacher of a happy class and the administration.... I cannot have much interaction with informatics infrastructure in the school because it seems to me that we speak in different languages. But it can be handled!!! Here what I am unhappy about is the childrenwho are out of interaction. They do not use any technology. I can only phone them, and I should say that they are shy even when they are talking to me. Unfortunately, we cannot achieve technological sincerity. " (Ö7)

The teachers' views on how interaction about the effectiveness of the ecosystem in which the elements of ICT were available were as in the following:

"Training should definitely be offered by people who are competent in teaching and who teach individuals in their age group. Because it is difficult to make progress in such training when there are older teachers. So, teachers of the same level should be trained at different times. It is more applicable when it is accessible. For example, we were trained in Google documents two years ago. The school administration also announced that the plans would be stored on the internet, and not on office programmes. After that, we mentioned the disruptions and problems in application and we decided altogether on a more beneficial working environment." (Ö10)

The next section includes the conclusions reached in this study and the discussions on the conclusions. 


\section{RESULTS and ARGUMENTS}

The research findings clearly describe that there is a digital divide in terms of students' access to technology. In other words, socio-economic level is the basic criterion in access to information technologies and in using them for learning according to the participants' views. Besides, the fact that some students' parents lost their job during the pandemic confirmed the digital divide. It was a result in parallel to the ones that socio-economic differences increased digital divide in education, that digital divide was prominent especially in socio-economically low groups and in disadvantaged regions and that the divide hindered equality of opportunity in education- which were obtained in relevant literature (Y1lmaz and Ersoy, 2012; Mayes, Natividad and Spector, 2015; Rodríguez and Sandoval, 2017; Romo, 2017; Reyes, 2019). Such factors as the lack of computer equipment, the wrong management of resources and the unavailability of curricula helping teachers and students to learn digital equipment (Reyes, 2019) in educational institutions in regions with low socio-economic status cause increases in digital divide and the emergence of inequality of opportunity (Moore, Vitale and Stawinoga, 2018). The government's responsibilities in reducing digital divide and inequality of opportunity and in minimising the problems students are probable to encounter should not be forgotten (Hueseo, 2020). Schools function as a mechanism in attaining equality of opportunity through educational opportunities they offer within the framework of the liabilities of a social state, and they also make it possible for students with low socio-economic level to access to information technologies in balancing digital divide (Andersen and Andersen, 2017; Rodriguez and Sandoval, 2017).

Both groups of teachers in this study called attention to difficulties stemming from students age in distance education activities done during the pandemic. Children's access to the internet and family-related variables in addition to students' age can emerge as limitations in a study (Hart, 2018). The studies performed and the reports presented in the literature suggest that distance education can be inadequate in the case of certain age groups, grade levels, courses and students (TEDMEM, 2020a) and that families have concerns about the types of technologies children reach, about privacy and about technology addiction due to children's age (Downes, Cesare, Gallagher and Rowsell, 2020).

The results obtained in relation to the sub-problem of difficulties that the teachers who teach in schools of differing socio-economic levels while using ICT demonstrated that the teachers with high awareness of educational technologies and skills tried to overcome the limitations by using Youtube and social media 
during Covid-19 and that some of the teachers who taught in private schools could eliminate the deficiencies even though they were incompetent in using technology thanks to resources readily offered by their school. Even though the efforts made by teachers with high levels of technological literacy to overcome the difficulties in their students' access by using the social media and various platforms is considered as efficacy in terms of teacher skills, it can also be regarded as the concrete evidence for digital divide from the aspect of students who have no access to the internet or no technical equipment in the process. Besides, the availability of digital learning materials and of environments for access in private schools with high socio-economic level causes inequality of opportunity on the part of students. O'Dwyer, Russell and Bebell (2004) point out that the variability in elementary school teachers' use of technologies stems from differences at the scale of school and district and that a considerable part of differentiation between schools is explained with the properties of schools and regions.

The views of teachers who work in schools with different socio-economic levels on the effects of economic and sociological limitations on access to technology and to learning environments through use, on students' equal access to educational opportunities and on their personal development during the pandemic were asked. The results obtained in this context indicated that the teachers working in schools with low socio-economic level had difficulty in reaching their students through technology but that the teachers working in schools with high socioeconomic level did not have such problems. Another result remarkable here was that institutional solutions can be created when the teachers who taught in private schools encountered technology-based problems whereas the teachers who taught in state schools had to wait for in-service training and family support on encountering such problems. In a similar way, it is pointed out in the report entitled "Effects of Covid-19 on Distance Learning and on the Future of Education" prepared by UNESCO (2020) that many private schools were knowledgeable about using technology to promote learning prior to the crisis, that therefore they did not have much difficulty in the process, that state schools could monitor their students once a week and that they had to choose such options as interaction between teachers and students through smart phones.

The first of the two variables influential in teachers' views on using ICT in the process of education-instruction is teachers' competence in ICT and the second is their socio-economic work environment. Consistently with relevant literature (Romo, 2017), some of the teachers who took part in the study said that they did not have difficulties in the use of, access to and participation in technology while some others said that they had difficulties in connection, time, education and instruction. The teachers who taught in schools with high socio-economic level did 
not have difficulties even though they were incompetent in using ICT because they are provided with possibilities, adequate technical and physical support and training on use by their school diminish the difficulties. The limitations in ICT, the difficulties experienced by teachers and digital divide can be reduced (Romo, 2017) by offering opportunities for professional development involving more public support and digital literacy (Xu, Ra \& Panth, 2020).

The results of the study showed that the interactions between teachers, students, administrators and parents- the group of educational stakeholdersincreased during Covid-19 and communication between them was made faster. The fact that information technologies will promote interactions between teachers, students, support personnel, content and technological environments and thus will make learning environments more dynamic and will create knowledge through collaborative and flexible learning (Britto Pereira and Ruas Lima, 2015) is in parallel to the results obtained in this study. The finding that the interaction between the stakeholders in the ecosystem in which the elements of ICT were available during Covid-19 had increased was important in reducing digital divide and unequal distribution in such cases as natural disasters, political tension and epidemic (UNESCO, 2020) and in the necessity of sustaining the interactions between the stakeholders to support the active solutions in the next process. The formation of positive ecosystem for the increase in communication and interaction between the stakeholders during Covid-19 is influential in implementing the decisions made in pluralistic and participatory manner. Making such decisions is thought to contribute to public education with mentality of social state.

\section{CONCLUSION and RECOMMENDATIONS}

This study that underscored the digital divide emerged as a result of failure to provide teachers working in schools of low and high socio-economic levels with equality of opportunity in education. These findings lead to significant educationalinstructional inferences about such issues as students efficacies, teacher skills, access to technological resources and cooperation between stakeholders- because several teachers will have used digital learning tools as much as they had never used before, will have made efforts to meet students on such platforms and will have gained new experience and skills by the time the epidemic is left behind (TEDMEM, 2020b). The results imply that the great differences between schools in information technologies and the existence of schools which cannot have access to EBA due to their problems in infrastructure are remarkable. In addition to that, some of the students who wish to benefit from EBA do not have such possibilities as personal computers, Tablet PCs or access to the internet. 
A number of precautions should be taken to secure equality of opportunity in access to and using technology in education and to sustain the interactions between stakeholders during and after Covid-19. Recommendations made by international institutions (UNICEF, 2020; UNESCO, 2020; ISTE; 2020) should also be taken into consideration to benefit from global experience. A number of recommendations can be made to the Ministry of National Education and to future researchers on the basis of the results obtained in this study.

The recommendations to MoNE include the following:

- Equal and fair public service should be provided for students to access to technology and to use it for learning purposes in order to prevent digital divide.

- The differences between schools should be minimised, the technological infrastructure and physical possibilities of schools should be improved and the needs of schools with financial impossibilities should be met so as to achieve equality of opportunity and justice in education.

- Such work as updating interactive books used by EBA through lesson presentation videos, tests and applications should continue.

- Internet service provided by MoNE for schools should be strengthened so that teachers, students and parents can benefit from EBA content.

- The model of live synchronic class- which was experienced and found to be successful during Covid-19- is needed. Simple tablet PCs which are affordable to all segments of society should be available on the market.

- Teachers should be offered training in using information and communication technologies effectively.

- The teachers who work in rural areas and disadvantaged regions should be offered more flexible work conditions and they should be provided with more support since the schools and students in such places need more support.

The recommendations to future researchers include the following:

- This study used qualitative research design. Teachers' views on digital divide can be obtained by using quantitative or mixed design.

- This study was conducted with the participation of elementary school teachers. Similar studies can be conducted with the inclusion of prospective teachers, primary school students or teachers of differing branches and stages of education. 
- Observation-based studies which include the reflections of digital dividea concept with strong sociological implications across the globe- into areas of life outside education are also needed.

\section{REFERENCES}

Andersen, I. G. \& Andersen, S. C. (2017). Student-centered instruction and academic achievement: Linking mechanisms of educational inequality to schools' instructional strategy. British Journal of Sociology of Education, 38(4), 533-550. https://doi.org/10.1080/01425692.2015.1093409

Britto Pereira, D.C. \& Ruas Lima, K.C.S. (2015). Information and communication technologies in education and practice basic educational: A possible relationship. Revista EDaPECI, 15, (3), 648-655.

Büyüköztürk, Ş., Kılıç Çakmak, E., Akgün, Ö. E., Karadeniz, Ş., \& Demirel, F. (2013). Bilimsel Araştırma Yöntemleri. Pegem Akademi.

Downes, T., Cesare, D.M., Gallagher, T.L. \& Rowsell, J. (2020). Parents' beliefs about and associations to their elementary children's home technology usage. Education and Information Technologies, 25. https://doi.org/ 10.1007/s10639-020-10188-2

Gündüz, H.B. (2010). Digital divide in Turkish primary schools: Sakarya sample. The Turkish Online Journal of Educational Technology, 9(1), 43-53.

Hart, K. (2018). The Homework Divide: 12 million schoolchildren lack internet. AXIOS. https://www.axios.com/the-homework-gap-kids-without-homebroadband-access-3ad5909f-e2fb-4208-b4d0-574c45ff4fe7.html, Access date: 12.05 .2020 .

Hueseo, L. C. (2020). Digital education taken seriously and the right to education in times of the coronavirus. Education and Law Review, 21.

Karaman, M. K. \& Kurfallı, H. (2008). Sınıf öğretmenlerinin bilgi iletişim teknolojilerini öğretim amaçlı kullanım düzeyleri. Kuramsal Eğitim Bilim, $1(2), 43-56$.

Kişi başına GSYH (2020). https://biruni.tuik.gov.tr/ilgosterge/?locale=tr, Erişim tarihi: 05.04.2020. 
Elementary School Teachers’ Experiences of Information and Communication...

Kuiper, E. \& Volman, M. (2009). The Web as a source of information for students in K-12 education. In Julie Coiro, Michele Knobel, Colin Lnakshear, Donald J. Leu (Eds.) Handbook of Research on New Literacies. Routledge Taylor and Francis Group.

Kurtdede Fidan, N., Erbasan,Ö, \& Kolsuz, S. (2016). Sınıf öğretmenlerinin eğitim bilişim ağından (EBA) yararlanmaya ilişkin görüşleri. Uluslararası Sosyal Araştırmalar Dergisi, 9(45), 626-637.

Li, Y., \& Ranieri, M. (2013). Educational and social correlates of the digital divide for rural and urban children: A study on primary school students in a provincial city of China. Computers \& Education, 60, (1), 197-209.

Mayes, R., Natividad, G. \& Spector, J.M. (2015). Challenges for educational technologists in the 21st century. Education Sciences, 5, 221-237. Doi: 10.3390/educsci5030221.

Miles, M. B., \& Huberman, A. M. (1994). Qualitative data analysis (2nd ed.). Thousan Oaks.

Miles, B., M. \& Huberman, A., M. (2015). Genişletilmiş bir Kaynak Kitap: Nitel Veri Analizi. (Çev. Ed. Sadegül Akbaba Altun, Ali Ersoy). Pegem Akademi.

Moore, R., Vitale, D. \& Stawinoga, N. (2018). The digital divide and educational equity. ACT Research \& Center for Equity in Learning. https://www.act.org/content/dam/act/unsecured/documents/R1698-digitaldivide-2018-08.pdf, Erişim tarihi: 11.05.2020.

O’Dwyer, L. M., Russell, M. \& Bebell, D. J. (2004). Identifying teacher, school and district characteristics associated with elementary teachers' use of technology: A multilevel perspective. Education Policy Analysis Archives, 12(48).

Pena- Lopez, I. (2010). From laptops to competences: bridging the digital divide in education. RUSC Universities and Knowledge Society Journal, 7(1), 2132.

Reyes, J.S. (2019). The digital divide in rural schools: A case study. International Journal of Technology and Educational Innovation, 5, (2).

Rodríguez, C. \& Sandoval, D. (2017). Digital stratification: ICT access and use in chilean students. Revista Electrónica de Investigación Educativa, 19(1), 2134. https://doi.org/10.24320/redie.2017.19.1.902

Romo, N.M. (2017). ICT and pupils of rural areas: between the digital gap and inclusive education. Sociedad Española de Pedagogía, 69(3), 41-56. 
Snelling, J. \& Fingal, D. (2020). 10 strategies for online learning during a coronavirus outbreak. ISTE (International Society for Technology in Education) https://www.iste.org/explore/10-strategiesonline-learningduring-coronavirus-outbreak, Erişim tarihi: 12.05.2020.

TEDMEM (2020a). COVID-19 salgını sürecinde öğretmenler. https://tedmem. org/covid-19/covid-19-salgini-surecinde-ogretmenler, Erişim tarihi: 10.05 . 2020.

TEDMEM (2020b). COVID-19: Okulların Kapatılmas1 ve Sonras1. https://tedmem.org/vurus/covid-19-okullarin-kapatilmasi-ve-sonrasi, Erişim tarihi: 10.05 .2020 .

TEGV (2020). Covid 19 dönemi TEGV çocukları uzaktan eğitim durum değerlendirme raporu. https://tegv.org/dosyalar/covid-19-donemi-uzaktanegitim-durum-degerlendirme-raporu.pdf, Erişim tarihi: 30.05.2020.

UNESCO (2020). Some implications of COVID-19 for remote learning and the future of schooling. https://unesdoc.unesco.org/ark:/48223/pf0000373229, Erişim tarihi: 10.05 .2020 .

UNICEF (2020). Key Messages and Actions for COVID-19 Prevention and Control in Schools https://www.who.int/docs/default-source/coronaviruse/ key-messages-and-actions-for-covid-19 prevention-and-control-in-schoolsmarch2020.pdf?sfvrsn=baf81d52_4\&gclid=CjwKCAjwte71BRBCEiwAU _V9h66B-rKjbSQGktaiPJbdRegV65u6WJsXyDUVdbJ9n9BicUX7gL2r BoCE8sQAvD_BwE, Erişim tarihi: 12.05.2020.

Van Dijk, J.A.G.M. (2006). Digital divide research, achivements and shortcommings. Poetics, 34, 221-235.

Xu, J.J., Ra, S., \& Panth, B. (2020). Lessons learned from the massive shift to online learning due to COVID-19. Asian Development Blog. https://blogs.adb.org/lessons-learned-from-the-massive-shiftto-onlinelearning-due-to-COVID-19, Erişim tarihi: 12.05.2020.

Yıldırım, A. \& Şimşek, H. (2016). Sosyal Bilimlerde Nitel Araştırma Yöntemleri (10. Bask1). Seçkin Yayıncılık.

Yıldız Durak, H. \& Seferoğlu, S.S.(2016). PISA sonuçlarının sayısal uçurumun göstergeleri açısından karşılaştırılması: Türkiye, Finlandiya ve Kore örnekleri. Kastamonu Ĕ̈itim Dergisi, 24, (1), 1-16. 
Elementary School Teachers' Experiences of Information and Communication...

Yılmaz, F. \& Ersoy, A. (2012). Beşinci sınıf öğrencileri arasındaki dijital bölünmenin çeşitli değişkenler açısından incelenmesi: Diyarbakır ili örneği. Mersin Üniversitesi Eğitim Fakültesi Dergisi, 8(1), 29-42.

2023 Eğitim Vizyonu. 2023vizyonu.meb.gov.tr, Erişim tarihi: 25.05.2019 tarihinde erişilmiştir.

\section{EXTENDED ABSTRACT}

Problem: Information and Communication Technologies [ICT] are heavily used today in access to knowledge as well as in creating, spreading, storing, managing knowledge and in communicating. The increasing effects of ICT technologies due to Covid-19 on social life have also been reflected into educational environments, undoubtedly. Since face to face education was suspended in March 2020 in Turkey as in the whole world due to Covid-19 pandemic, distance education was put into practice at all stages of education in Turkey by the Ministry of National Education [MoNE] and by the Council of Higher Education, the EBA was updated, the videobased lessons were taught on TV for nationwide access and solutions of educational access at school level and at grade level were introduced. It was observed in this process that distance education was conducted through synchronic commercial platforms in private schools but that it was performed by using free distance learning channels with individual efforts of elementary school teachers in state schools. The process introduced new and important experiences for people in educational institutions. According to the distance education evaluation report (2020) prepared by Turkish educational volunteers foundation, the rate of students who followed EBA regularly every day during covid-19 pandemic was $69 \%$ while the rate of participation in live classes was $11 \%$. During pandemic, $83 \%$ of access to distance education was through TV channels. Of the students $50 \%$ used their computer, 59\% used their mobile phone, $28 \%$ used their tablet PC and $4 \%$ used no devices in distance education. The rate of students who saw their teacher regularly every week was $48 \%$ while the rate of those who saw their teacher once or twice a week was $31 \%$ and the rate of those who saw their teacher once or twice in the last 90 days was $21 \%$. The rate of those who communicated with their teacher irregularly or rarely was $51 \%$. Even though information and communication technologies have a large impact across the world, the impacts vary due to socioeconomic level, the power of relations or inadequate conditions (Pena-Lopez, 2010). Van Dijk (2006, 221-222) describes digital divide as the gap between those who can access to information technologies and those who cannot while stating that attention was called to the concept of digital divide in the late 1990s in unequal access to the new media and in the use of technology. The ICT experiences and 
observations of teachers who teach in schools with varying socio-economic levels in Turkey should be demonstrated from the perspectives described above.

Purpose: The current study aims to describe elementary school teachers' experiences of ICT on the basis of the digital divide by seeking answers to the following research questions:

1. How do elementary school teachers who teach in schools with differing socio-economic levels use ICT in their classes?

2. What difficulties do they encounter in using ICT?

3. What do they think of the effects of varying possibilities to access to technology due to socio-economic restrictions on learning environment, on students' equal access to educational opportunities and on their personal development?

4. What are their evaluations about the effectiveness of the ecosystem in which the elements of ICT are available?

Method: This study was designed as a holistic multiple case study. Deviant case sampling, a method of purposeful sampling, was used in this study. Accordingly, 16 teachers 8 of whom were teaching in a school with low socio-economic level and 8 of whom were teaching in a school with high socio-economic level were included in the study group in Ankara. Standardised open-ended interview forms were used in collecting the research data. The 19 interview questions prepared for our purposes were sent to the teachers synchronously and asynchronously during Covid-19 pandemic. Content analysis- one of the document analysis methods used in qualitative research- was used in analysing the answers.

Findings: The findings were presented on the basis of the four main themes which emerged in the scope of this study. The themes were the use of ICT during Covid19 pandemic, the difficulties encountered in using the ICT in this process and the recommendations for solutions, the economic and sociological limitations during Covid-19 pandemic and the ecosystem in which the elements of ICT were available during Covid-19 pandemic.

Results and Argument: The research findings clearly describe that there is a digital divide in terms of students' access to technology. In other words, socioeconomic level is the basic criterion in access to information technologies and in using them for learning according to the participants' views. Both groups of 
teachers in this study called attention to difficulties stemming from students age in distance education activities done during the pandemic.

The results obtained in relation to the sub-problem of difficulties that the teachers who teach in schools of differing socio-economic levels while using ICT demonstrated that the teachers with high awareness of educational technologies and skills tried to overcome the limitations by using Youtube and social media during Covid-19 and that some of the teachers who taught in private schools could eliminate the deficiencies even though they were incompetent in using technology thanks to resources readily offered by their school. Even though the efforts made by teachers with high levels of technological literacy to overcome the difficulties in their students' access by using the social media and various platforms is considered as efficacy in terms of teacher skills, it can also be regarded as the concrete evidence for digital divide from the aspect of students who have no access to the internet or no technical equipment in the process. The results of the study showed that the interactions between teachers, students, administrators and parents- the group of educational stakeholders- increased during Covid-19 and communication between them was made faster. A number of recommendations can be made to the Ministry of National Education and to future researchers on the basis of the results obtained in this study.

The recommendations to MoNE include the following:

- Equal and fair public service should be provided for students to access to technology and to use it for learning purposes in order to prevent digital divide.

- The differences between schools should be minimised, the technological infrastructure and physical possibilities of schools should be improved and the needs of schools with financial impossibilities should be met so as to achieve equality of opportunity and justice in education.

- Such work as updating interactive books used by EBA through lesson presentation videos, tests and applications should continue.

- Internet service provided by MoNE for schools should be strengthened so that teachers, students and parents can benefit from EBA content.

- The model of live synchronic class- which was experienced and found to be successful during Covid-19- is needed. Simple tablet PCs which are affordable to all segments of society should be available on the market.

- Teachers should be offered training in using information and communication technologies effectively.

- The teachers who work in rural areas and disadvantaged regions should be offered more flexible work conditions and they should be provided with more support since the schools and students in such places need more support. 
The recommendations to future researchers include the following:

- This study used qualitative research design. Teachers' views on digital divide can be obtained by using quantitative or mixed design.

- This study was conducted with the participation of elementary school teachers. Similar studies can be conducted with the inclusion of prospective teachers, primary school students or teachers of differing branches and stages of education.

- Observation-based studies which include the reflections of digital divide- a concept with strong sociological implications across the globe- into areas of life outside education are also needed. 